\title{
Safety Assessment of Dairy Microorganisms, Streptococcus thermophilus and Lactobacillus bulgaricus, Isolated from Traditional Yoghurt Cultures
}

\author{
Yekta Gezginç $^{1 *}$, Fatma Gül Demirbanka², Elif Coşkun Dağgeçen², İsmail Akyol² \\ ${ }^{I}$ Department of Food Engineering, Faculty of Engineering and Architecture, Kahramanmaraş Sütcü Imam University, 46060/Avşar, \\ Kahramanmaraş, Turkey \\ ${ }^{2}$ Biotechnology Department, Biotechnology and Gene Engineering Laboratory, Kahramanmaraş Sütcü İmam University, Agriculture \\ Faculty, Agricultural 46060/ Avşar, Kahramanmaraş, Turkey

A R T ICLE IN F O A B S TR A C T

\section{Research Article} \\ Received 02 January 2018 \\ Accepted 04 June 2018 \\ Keywords: \\ Antibiotic resistance \\ Yoghurt \\ Streptocoocus thermophilus \\ Lactobacillus bulgaricus. \\ Food safety \\ The traditional fermented food consumption has become very popular because of the \\ increasing public concern about food additives. Lactic Acid Bacteria (LAB) species have \\ traditionally been used as starter cultures in the production of fermented food. LAB can \\ acquire antibiotic resistance from other bacteria in the natural environment and different \\ resistant mechanisms via mutation. The resistance of bacteria to antibiotics is an \\ increasingly important public health problem worldwide. In this study, antibiotic \\ resistance of 115 Streptocoocus thermophilus and 35 Lactobacillus bulgaricus isolates \\ obtained from traditional Turkish yogurts were tested against kanamycin, \\ chloramphenicol, erythromycin, ampicillin, rifampicin, tetracycline, vancomycin and \\ gentamicin using disc diffusion method. Study results showed that most strains were \\ susceptible to all the antibiotics tested while a few of them were determined to be \\ resistant only to kanamycin, ampicillin, erythromycin, and tetracycline. When contacted \\ in a human body, resistant strains might transfer the related genes to the pathogenic \\ species, which may result in devastating consequences.
}

*Corresponding Author:

E-mail: yekgan@ksu.edu.tr

DOI: https://doi.org/10.24925/turjaf.v6i7.834-839.1778

\section{Introduction}

Lactic Acid Bacteria (LAB) species have traditionally been used as starter cultures in the production of fermented food such as cheese, butter and yogurt. Considering the long history of their presence and use in traditional fermented food, LAB have been presented in the status of "Generally Regarded as Safe" (GRAS) by the American Food and Drug Agency. LAB species are also commonly found among the resident microbiota of the gastrointestinal tract (GIT) of vertebrates (Carr et al., 2002). However, an increasing concern has arisen about multi antibiotic resistance features of bacteria in the light of the current knowledge.

Evaluation of antibiotic resistance in bacteria is mainly based on two factors; the presence of resistance genes and the selective pressure by the use of antibiotics (Levy and Marshall, 2004). The presence of intrinsic and acquired antibiotic resistance genes in LAB do not bear a significant clinical risk. Conversely, the possibility that food safety cultures might transfer antibiotic resistance genes to pathogenic opportunistic species either during food manufacture or during passage through the gastrointestinal tract (GIT) is disquieting (Salyers et al., 2004; Ammor et al., 2007). Resistances by mutation are assumed as a low risk of horizontal spread, while acquired resistances mediated by the addition of genes introduce the real danger of transfer among the species (Normark and Normark, 2002). It is possible for LAB to acquire antibiotic resistances from other bacteria in the natural environment as well as distinct resistant mechanisms through mutations. Plasmid transfer must be considered as a system which has the potential to generate antibiotic resistant pathogenic bacteria. LAB used in starter cultures can capture antibiotic resistance genes from other bacteria with the aid of conjugative plasmids and transposons. It has been demonstrated that when antibiotic resistant gene carrier LAB strains are used as starters, these resistant genes could be mobilized and transferred to other bacteria including pathogens (Fraqueza, 2015).

Antibiotics kill or inhibit susceptible bacteria; however resistance bacterial genus or species carrying inherent (natural) or acquired genes remain unaffected (Normark and Normark, 2002). Generating resistance against antibiotics in originally susceptible microorganisms has become a major threat to public health (Mazel and Davies, 1999). The resistance of bacteria to antibiotics is an increasingly important public 
health problem worldwide. It has been reported that in 11 European countries, antibiotic resistance is correlated with antibiotic use (Bronzwaer et al., 2002). Decades of antibiotic use have resulted in bacterial resistance to many known antibiotics. Each year, in world, antibioticresistant bacteria sicken many people, and most of them die as a direct result of these infections. The food chain has been recognized as one of the main ways of transmission of antibiotic resistance from pathogens to potential starter bacterial population (Teuber et al., 1999).

The traditional fermented food consumptions have become very popular issue reflecting food additives. On the other hand, consumers do not consider antibiotic resistance features and safety aspects of traditional starter. Besides, non-commercial strains might be a rich reservoir of unique genetic material (Petrova and Gouliamova, 2006). LAB isolated from chicken resistance to the familiar antibiotics used in the farm (Shazali et al., 2014) and $S$. thermophilus isolates carrier for antibiotic resistance determinants in commercial cheese (Wang et al., 2006). Streptococcus thermophilus and Lactobacillus bulgaricus are non-pathogenic organisms and are important LAB strains in yoghurt industry. The $115 \mathrm{~S}$. thermophilus and $35 \mathrm{Lb}$. bulgaricus strains evaluated here were originally isolated from traditional yoghurts in our previous study (Gezginc et al., 2015). The aim of this study was the molecular identification of a large collection of LAB strains from traditional yoghurts and to assess their antibiotic resistance features thus to reveal the potential risks of these isolates in terms of food safety when used as starters.

\section{Material and Method}

\section{Molecular Identification of Strains}

A total of 115 Streptocoocus thermophilus and 35 Lactobacillus bulgaricus species used in this study were isolated from yoghurt in a previous study (Gezginc et al., 2015). S. thermophilus isolates were grown in $1 \%(\mathrm{w} / \mathrm{v})$ sucrose containing M17 medium at $42^{\circ} \mathrm{C}$ and $L b$. bulgaricus isolates were grown in MRS medium at $37^{\circ} \mathrm{C}$. DNA templates extracted from a single bacterial colony do not require further purification after being boiled and can be directly used for PCR amplification. Molecular identification of the strains was performed with $16 \mathrm{~S}$ rRNA region sequencing. Bacterial domain specific $365 \mathrm{~F}$ (ACWCCTACGGGWGGCWGC) and 1064R (AYCTCACGRCACGAGCTGAC) primers (Winsley et al., 2012) were purchased from Iontek (Istanbul, Turkey).
Polymerase chain reaction was performed in $40 \mu \mathrm{L}$ by using $5 \mathrm{U} / \mu \mathrm{L}$ DNA polymerase (Thermo Scientific, Waltham, MA) and $10 \times$ PCR buffer (Thermo Scientific). A total of 20 pmol of each primer was used, and deoxynucleoside triphosphates (Thermo Scientific) were used at a concentration of $250 \mu \mathrm{M}$ for each. The PCR amplification program consisted of 1 cycle of $95^{\circ} \mathrm{C}$ for 5 min, 30 cycles of $95^{\circ} \mathrm{C}$ for $30 \mathrm{~s}, 54^{\circ} \mathrm{C}$ for $1 \mathrm{~min}, 72^{\circ} \mathrm{C}$ for $1.5 \mathrm{~min}$ and 1 cycle of $72^{\circ} \mathrm{C}$ for $7 \mathrm{~min}$. The amplification products $(746 \mathrm{bp})$ were then separated by electrophoresis in $1.5 \%(\mathrm{w} / \mathrm{v})$ agarose gel. Ethidium bromide $(0.5 \mu \mathrm{g} / \mathrm{ml})$ staining was utilized to visualize the amplicons under UV transillumination. The amplified PCR products were cleaned using the Qiaquick gel extraction kit (Qiagen, Valencia, CA, USA) and were sent to Iontek (Istanbul, Turkey) for nucleotide sequencing. Observed sequence data were compared GenBank database using the basic local alignment search tool (BLAST) provided by the National Center for Biotechnology Information (NCBI) public domain.

\section{Antibiotics Susceptibility Testing}

Antibiotic features of the identified S. thermophilus and $L b$. bulgaricus isolates were tested by disc diffusion method on SM17 and MRS agar plates, correspondingly. All isolates were screened for their susceptibility to kanamycin, chloramphenicol, erythromycin, ampicillin, rifampicin, tetracycline, vancomycin and gentamicin. Appropriate antibiotic stock concentration was made in 5 $\mathrm{mL}$ medium and then working dilution series were prepared from stock solution (Table 1). To prepare antibiotic discs, whatman filter paper No. 3 was cut using puncher $(5 \mathrm{~mm}$ in diameter) and disc paper was sterilized in an autoclave. $20 \mu \mathrm{L}$ of working antibiotics solution (each antibiotic at its pre-determined concentration) were added on sterile filter paper discs using a pipette and the discs were dried in laminar flow cabinet. Once dried, they were stored in sealed tubes at minus $20^{\circ} \mathrm{C}$ until used. In order to determine the antibiotic resistances, the plates were inoculated with $100 \mu \mathrm{L}$ of an individual isolate at $10^{5}$ colony-forming unit $(\mathrm{cfu}) / \mathrm{mL}$ concentration. Then five discs containing the antibiotic at different concentrations were placed onto the overlaid plates and incubate at $37^{\circ} \mathrm{C}$ ( Lb. bulgaricus) and $42^{\circ} \mathrm{C}$ (S. thermophilus). The diameters of inhibition halos (Minimum Inhibitory Concentration (MIC)) were measured in mm.zone (Figure 1) and experiment were performed in triplicate.

Table 1 Antibiotics used in this study.

\begin{tabular}{l|lc}
\multicolumn{1}{c}{ Antibiotics } & \multicolumn{1}{|c}{ Stock Concentration $(\mathrm{mg} / \mathrm{mL})$} & Tested Min-Max Concentration $(\mu \mathrm{g} / \mathrm{mL})$ \\
\hline Kanamycin & $5 \mathrm{mg} / \mathrm{mL}$; dissolved in $\mathrm{dH}_{2} \mathrm{O}$ & $0.625-5$ \\
Chloramphenicol & $5 \mathrm{mg} / \mathrm{mL}$; dissolved in absolute ethanol & $0.625-5$ \\
Erythromycin & $5 \mathrm{mg} / \mathrm{mL}$; dissolved in absolute ethanol & $1.25-10$ \\
Ampicillin & $5 \mathrm{mg} / \mathrm{mL} ;$ dissolved in $\mathrm{dH}_{2} \mathrm{O}$ & $1.25-10$ \\
Rifampicin & $40 \mathrm{mg} / \mathrm{mL}$; dissolved in $98 \%$ methanol & $12.5-100$ \\
Tetracycline & $5 \mathrm{mg} / \mathrm{mL}$; dissolved in absolute ethanol & $0.625-5$ \\
Vancomycin & $8 \mathrm{mg} / \mathrm{ml}$; dissolved in $\mathrm{dH}_{2} \mathrm{O}$ & $1-8$ \\
Gentamicin & $50 \mathrm{mg} / \mathrm{ml}$; dissolved in $\mathrm{dH}_{2} \mathrm{O}$ & $6.25-50$ \\
\hline
\end{tabular}



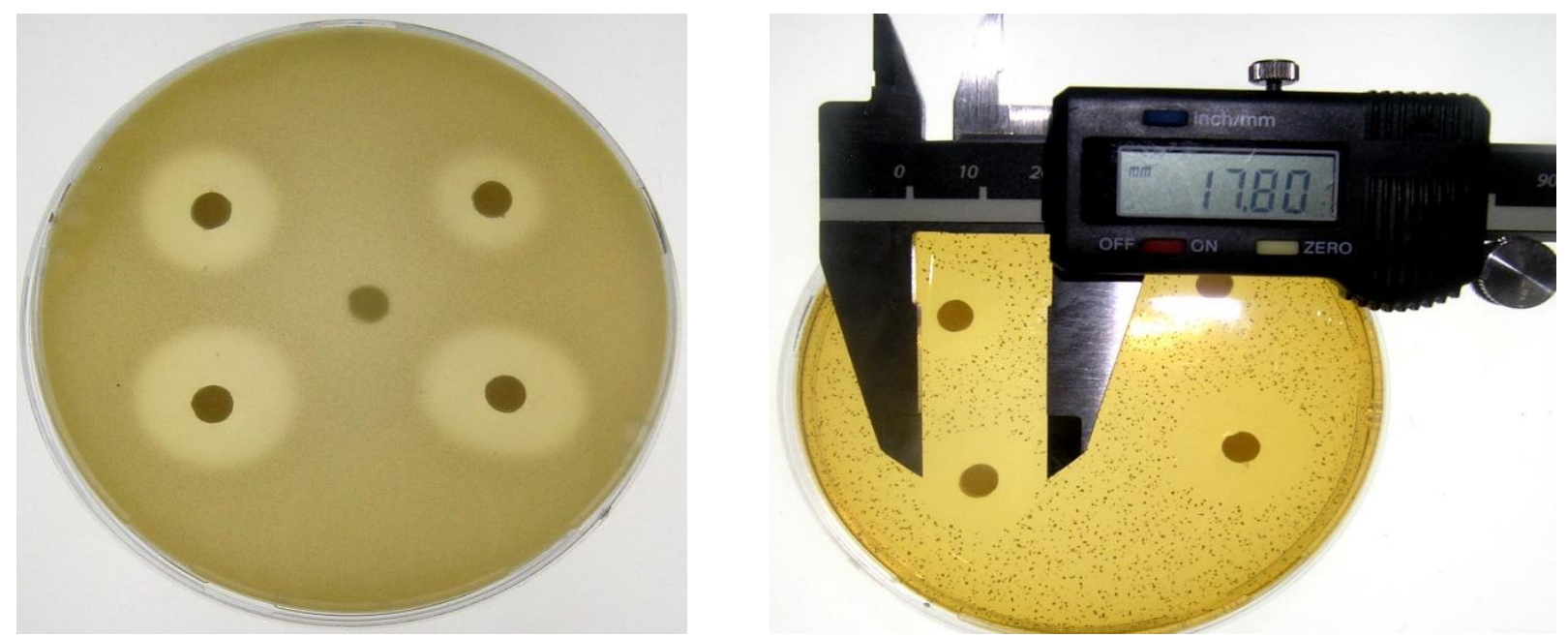

Figure 1 Determination and measurement of antibiotic inhibition zone

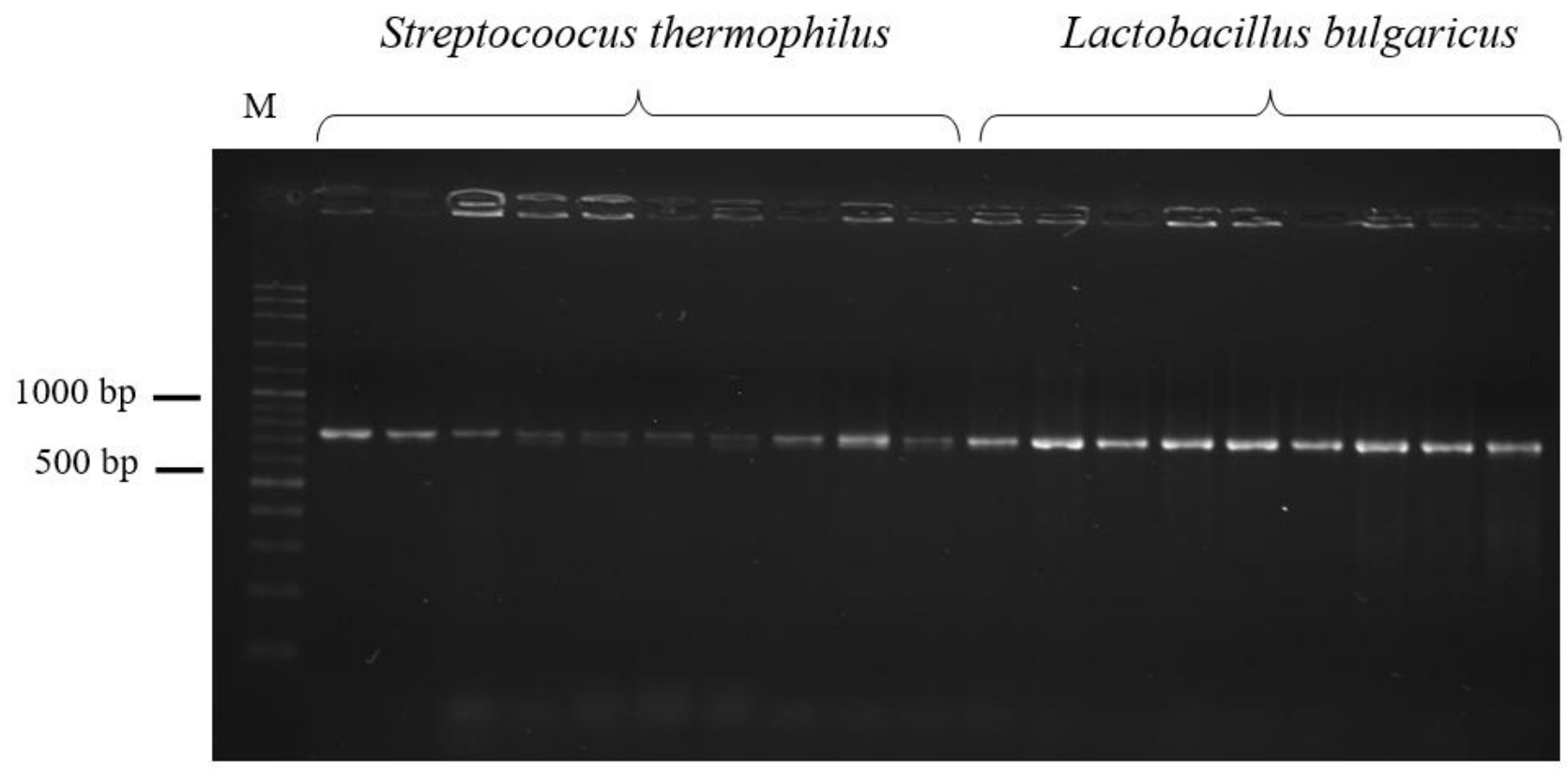

Figure 2 PCR amplification of 16S rDNA region for Streptocoocus thermophilus and Lactobacillus bulgaricus isolates. M: DNA ladder

\section{Results and Discussion}

\section{Molecular Identification of Isolates}

The PCR amplification of $16 \mathrm{~S}$ rDNA by using universal $365 \mathrm{~F}$ and $1064 \mathrm{R}$ primers produced a single band at the expected size which was obtained with a $54^{\circ} \mathrm{C}$ annealing temperature. The length of the PCR fragment was approximately $746 \mathrm{bp}$ (Figure 1). The amplified 16S rDNA fragments were sequenced in order to verify the accuracy of isolate identification.16S rDNA fragment sequence of each isolate was read in three replications using either forward or reverse primer. Nucleotide alignments were constructed using Clustal X (Thompson et al., 1997) and a single consensus sequence was generated. The consensus sequences of PCR fragments generated high percent matches $(99-100 \%)$ with those of the corresponding genes from the genome database.

\section{Antibiotic Resistance of Isolates}

Minimal inhibitory concentration (MIC) values for all bacterial isolates were determined using liquid medium and observed MIC of used antibiotics were given in Table 1. Identified 150 isolates ( $S$. thermophilus (115) and $L b$. bulgaricus (35)) have been submitted to the antibiotic susceptibility test for eight different antibiotics. Each antibiotic was tested at four different concentrations level and dissolved liquid $\left(\mathrm{dH}_{2} \mathrm{O}\right.$ or ethanol) was used as control. Antibiotics resistance or susceptible profile of $S$. thermophilus and Lb. bulgaricus isolates were determined according to diameter of inhibitory zone. Depending on the type of antibiotic and its concentration, numbers of the resistance strains of $S$. thermophilus and $L b$. bulgaricus were determined and the results were presented in Table 2 and 3. Yoghurt bacteria are generally susceptible to antibiotics inhibiting the synthesis of protein such as chloramphenicol, erythromycin, and tetracycline, and more resistant to aminoglycosides (kanamycin, and gentamicin). 
Table 2 Distribution of MICs of kanamycin, chloramphenicol, erythromycin, ampicillin, rifampicin, tetracycline, vancomycin and gentamicin for Streptococcus thermophilus isolates.

\begin{tabular}{|c|c|c|c|c|c|c|c|c|}
\hline \multirow{2}{*}{ Antibiotics } & \multirow{2}{*}{$\begin{array}{c}\text { Concentrations } \\
\mu \mathrm{g} / \mathrm{ml}\end{array}$} & \multicolumn{7}{|c|}{ Diameter of inhibition zone (mm) } \\
\hline & & $5 *$ & $6-11$ & $12-17$ & $18-23$ & $24-29$ & $30-35$ & $\geq 36$ \\
\hline \multirow{4}{*}{ Kanamycin } & 0.625 & $49(43)$ & $44(38)$ & $17(15)$ & $2(2)$ & $1(1)$ & $1(1)$ & $1(1)$ \\
\hline & 1.25 & $26(23)$ & $51(44)$ & $27(23)$ & $8(7)$ & $1(1)$ & $1(1)$ & $1(1)$ \\
\hline & 2.5 & $21(18)$ & $23(20)$ & $54(47)$ & $14(12)$ & $1(1)$ & $1(1)$ & $1(1)$ \\
\hline & 5 & $19(17)$ & $12(10)$ & $48(42)$ & $31(27)$ & $3(3)$ & $1(1)$ & $1(1)$ \\
\hline \multirow{4}{*}{ Chloramphenicol } & $6.25 \times 10^{-4}$ & $26(23)$ & $59(51)$ & $23(20)$ & $4(3)$ & $1(1)$ & $1(1)$ & $1(1)$ \\
\hline & $12.5 \times 10^{-4}$ & $9(8)$ & $37(32)$ & $53(46)$ & $10(9)$ & $4(3)$ & $1(1)$ & $1(1)$ \\
\hline & $25 \times 10^{-4}$ & $4(3)$ & $11(10)$ & $67(58)$ & $24(21)$ & $7(6)$ & $1(1)$ & $1(1)$ \\
\hline & $50 \times 10^{-4}$ & $2(2)$ & $4(3)$ & 39 (34) & $51(44)$ & $14(12)$ & $4(3)$ & $1(1)$ \\
\hline \multirow{4}{*}{ Erytromycin } & $12.5 \times 10^{-4}$ & $23(20)$ & $12(10)$ & $37(32)$ & $33(29)$ & $7(6)$ & $2(2)$ & $1(1)$ \\
\hline & $25 \times 10^{-4}$ & $20(17)$ & $7(6)$ & $21(18)$ & $42(37)$ & $20(17)$ & $3(3)$ & $2(2)$ \\
\hline & $50 \times 10^{-4}$ & $17(15)$ & $6(5)$ & $11(10)$ & $37(32)$ & $33(29)$ & $9(8)$ & $2(2)$ \\
\hline & $100 \times 10^{-4}$ & $13(11)$ & $5(4)$ & $10(9)$ & $26(23)$ & $39(34)$ & $15(13)$ & $7(6)$ \\
\hline \multirow{4}{*}{ Ampicillin } & $1.25 \times 10^{-4}$ & $24(21)$ & $10(9)$ & $37(32)$ & $27(23)$ & $13(11)$ & $3(3)$ & $1(1)$ \\
\hline & $2.5 \times 10^{-4}$ & $19(17)$ & $3(3)$ & $29(25)$ & $37(32)$ & $14(12)$ & $9(2)$ & $4(3)$ \\
\hline & $5 \times 10^{-4}$ & $16(14)$ & $3(3)$ & $17(15)$ & $34(30)$ & $27(23)$ & $10(9)$ & $8(7)$ \\
\hline & $10 \times 10^{-4}$ & $11(10)$ & $8(7)$ & $11(10)$ & $26(23)$ & $31(27)$ & 13 (11) & $15(13)$ \\
\hline \multirow{4}{*}{ Rifampycin } & $12.5 \times 10^{-4}$ & $17(15)$ & $7(6)$ & $43(37)$ & 19 (17) & $14(12)$ & $14(12)$ & $1(1)$ \\
\hline & $25 \times 10^{-4}$ & $10(9)$ & $5(4)$ & $28(24)$ & $31(27)$ & $16(14)$ & $15(13)$ & $10(9)$ \\
\hline & $50 \times 10^{-4}$ & $9(8)$ & $1(1)$ & 19 (17) & $36(31)$ & $23(20)$ & $16(14)$ & $11(10)$ \\
\hline & $100 \times 10^{-4}$ & $8(7)$ & $1(1)$ & $11(10)$ & $34(30)$ & $24(21)$ & $14(12)$ & $23(20)$ \\
\hline \multirow{4}{*}{ Tetracycline } & $6.25 \times 10^{-4}$ & $19(17)$ & $14(12)$ & $43(37)$ & $30(26)$ & $7(16)$ & $1(1)$ & $1(1)$ \\
\hline & $12.5 \times 10^{-4}$ & $16(14)$ & $6(5)$ & $32(28)$ & $35(30)$ & $22(19)$ & $3(3)$ & $1(1)$ \\
\hline & $25 \times 10^{-4}$ & $12(10)$ & $4(3)$ & $21(18)$ & $31(27)$ & $29(25)$ & $17(15)$ & $1(1)$ \\
\hline & $50 \times 10^{-4}$ & $10(9)$ & $2(2)$ & $13(11)$ & $25(22)$ & $39(34)$ & 19 (17) & $7(6)$ \\
\hline \multirow{4}{*}{ Vankomycin } & $6.25 \times 10^{-2}$ & $19(17)$ & $21(18)$ & $63(55)$ & $8(7)$ & $2(2)$ & $1(1)$ & $1(1)$ \\
\hline & $12.5 \times 10^{-2}$ & $17(15)$ & $13(11)$ & $51(44)$ & $26(23)$ & $6(5)$ & $1(1)$ & $1(1)$ \\
\hline & $25 \times 10^{-2}$ & $9(8)$ & $3(3)$ & $49(43)$ & $43(37)$ & $4(3)$ & $6(5)$ & $1(1)$ \\
\hline & $50 \times 10^{-2}$ & $18(16)$ & $1(1)$ & 22 (19) & $53(46)$ & $14(12)$ & $6(5)$ & $1(1)$ \\
\hline \multirow{4}{*}{ Gentamicin } & $12.5 \times 10^{-2}$ & $20(17)$ & $36(31)$ & $44(38)$ & $11(10)$ & $2(2)$ & $1(1)$ & $1(1)$ \\
\hline & $25 \times 10^{-2}$ & $17(15)$ & $5(4)$ & $49(43)$ & $37(32)$ & $5(4)$ & $1(1)$ & $1(1)$ \\
\hline & $50 \times 10^{-2}$ & $13(11)$ & $6(5)$ & 33 (29) & $39(34)$ & $21(18)$ & $2(2)$ & $1(1)$ \\
\hline & 1 & $8(7)$ & $8(7)$ & $12(10)$ & $43(37)$ & $37(32)$ & $5(4)$ & $2(2)$ \\
\hline
\end{tabular}

*Disk diameter

Kanamycin resistance of $S$. thermophilus and $L b$. bulgaricus isolates tested using various concentrations $(0.625,1.25,2.5$ and $5 \mathrm{mg} / \mathrm{mL})$ of the antibiotics on fixed discs. When $0.625,1.25,2.5$ and $5 \mathrm{mg} / \mathrm{mL}$ kanamycin concentrations were used, the percentage of resistant isolates was determined as 43, 23, 18 and $17 \%$ respectively in $S$. thermophilus isolates. Same concentrations $(0.625,1.25,2.5$ and $5 \mathrm{mg} / \mathrm{mL})$ were applied to $L b$. bulgaricus isolates and the resistance ratios were determined as 80,74, 66 and $54 \%$ respectively. A lower percentage $(17 \%)$ of $S$. thermophiles isolates were resistant to $5 \mathrm{mg} / \mathrm{mL}$ of kanamycin compared with $L b$. bulgaricus isolates which exhibited 54\% resistance for the same concentration of it. Antibiotic treatments with decreased kanamycin concentrations showed that the susceptible isolates were low in frequency. Additionally, the disc diffusion may not be accurate for detecting low concentration of antibiotics.

When various concentration of chloramphenicol applied to $S$. thermophilus and Lb. bulgaricus isolates, the results showed that $2 \%$ and $43 \%$ of isolates were resistant for $5 \mathrm{mg} / \mathrm{mL}$ chloramphenicol, respectively. Measured inhibition zone indicated that some isolates were susceptible to lower chloramphenicol concentrations as well. These findings agree with published data (Florez et al., 2005).

In another set up, erytromycin was applied in various concentration $\left(100-12.5 \times 10^{-4} \mathrm{mg} / \mathrm{mL}\right)$ to both species. In $S$. thermophilus isolates, resistant ratio to minimum and maximum concentrations used were determined as $11 \%$ and $20 \%$, respectively. In $L b$. bulgaricus isolates, resistant ratio to minimum and maximum concentrations, however, were $43 \%$ and $66 \%$ in respect to their order. Erytromycin susceptible isolates were found in both species.

Ampicillin concentration was used between 1.25- 10 $\mu \mathrm{g} / \mathrm{mL}$, and $S$. thermophilus and Lb. bulgaricus isolates were found to be $10 \%$ and $39 \%$ resistant for the maximum applied antibiotic dose, respectively. Ampicillin breakpoint was given as $4 \mu \mathrm{g} / \mathrm{mL}$ (Ammor et al., 2007) and some isolates were resistant more than this breakpoint. Rifampicin was dissolved in $40 \mathrm{mg} / \mathrm{mL}$ and four dilution concertations (Table 2) were applied. Resistance rateof $S$. thermophilus and Lb. bulgaricus isolates were determined as $7 \%$ and $31 \%$ at $40 \mu \mathrm{g} / \mathrm{mL}$ Rifampicin. When tetracycline antibiotics used at its highest concentration $(40 \mu \mathrm{g} / \mathrm{mL}), 9 \%$ of $S$. thermophilus and $46 \%$ of Lb. bulgaricus strains were detected as resistant. Stock solution of Vancomycin and Gentamicin 
were made in $8 \mu \mathrm{g} / \mathrm{mL}$ and $40 \mu \mathrm{g} / \mathrm{mL}$ concentrations and resistant strains were determined to occupy $16 \%$ and $7 \%$ of $S$. thermophilus isolates, respectively. The percentages of resistant $L b$. bulgaricus isolates were determined as $31 \%$ and $46 \%$. These observations were in accordance with a pervious report through which 34 S. thermophilus strains isolated from Turkish yoghurts and their antibiotic resistance patterns were examined. The authors declared that most strains of $S$. thermophilus they studied were found to be resistant to gentamicin (79\%) (Aslim et al., 2004).

Table 3 Distribution of MICs of kanamycin, chloramphenicol, erythromycin, ampicillin, rifampicin, tetracycline, vancomycin and gentamicin for Lactobacillus bulgaricus isolates.

\begin{tabular}{|c|c|c|c|c|c|c|c|c|}
\hline \multirow{2}{*}{ Antibiotics } & \multirow{2}{*}{$\begin{array}{c}\text { Concentrations } \\
\mu \mathrm{g} / \mathrm{ml}\end{array}$} & \multicolumn{7}{|c|}{ Inhibition halo (mm) } \\
\hline & & $5 *$ & $6-11$ & $12-17$ & $18-23$ & $24-29$ & $30-35$ & $\geq 36$ \\
\hline \multirow{4}{*}{ Kanamycin } & 0.625 & $28(80)$ & $2(6)$ & $1(3)$ & $1(3)$ & $1(3)$ & $1(3)$ & $1(3)$ \\
\hline & 1.25 & $26(74)$ & $4(11)$ & $1(3)$ & $1(3)$ & $1(3)$ & $1(3)$ & $1(3)$ \\
\hline & 2.5 & $23(66)$ & $4(11)$ & $3(9)$ & $2(6)$ & $1(3)$ & $1(3)$ & $1(3)$ \\
\hline & 5 & $19(54)$ & $3(9)$ & $6(17)$ & $3(9)$ & $2(6)$ & $1(3)$ & $1(3)$ \\
\hline \multirow{4}{*}{ Chloramphenicol } & $6.25 \times 10^{-4}$ & $26(74)$ & $2(6)$ & $3(9)$ & $1(3)$ & $1(3)$ & $1(3)$ & $1(3)$ \\
\hline & $12.5 \times 10^{-4}$ & $22(63)$ & $2(6)$ & $7(20)$ & $1(3)$ & $1(3)$ & $1(3)$ & $1(3)$ \\
\hline & $25 \times 10^{-4}$ & $17(49)$ & $4(11)$ & $9(26)$ & $2(6)$ & $1(3)$ & $1(3)$ & $1(3)$ \\
\hline & $50 \times 10^{-4}$ & $15(43)$ & $1(3)$ & $3(3)$ & $12(34)$ & $2(6)$ & $1(3)$ & $1(3)$ \\
\hline \multirow{4}{*}{ Erytromycin } & $12.5 \times 10^{-4}$ & $23(66)$ & $3(9)$ & $3(9)$ & $2(6)$ & $2(6)$ & $1(3)$ & $1(3)$ \\
\hline & $25 \times 10^{-4}$ & $18(51)$ & $4(11)$ & $5(14)$ & $3(9)$ & $3(9)$ & $1(3)$ & $1(3)$ \\
\hline & $50 \times 10^{-4}$ & $16(46)$ & $3(9)$ & $7(20)$ & $5(14)$ & $2(6)$ & $1(3)$ & $1(3)$ \\
\hline & $100 \times 10^{-4}$ & $15(43)$ & $6(17)$ & $4(11)$ & $5(14)$ & $3(9)$ & $1(3)$ & $1(3)$ \\
\hline \multirow{4}{*}{ Ampicillin } & $1.25 \times 10^{-4}$ & $23(66)$ & $5(14)$ & $3(9)$ & $1(3)$ & $1(3)$ & $1(3)$ & $1(3)$ \\
\hline & $2.5 \times 10^{-4}$ & $20(57)$ & $6(17)$ & $4(11)$ & $2(6)$ & $1(3)$ & $1(3)$ & $1(3)$ \\
\hline & $5 \times 10^{-4}$ & $16(46)$ & $5(14)$ & $8(23)$ & $3(9)$ & $1(3)$ & $1(3)$ & $1(3)$ \\
\hline & $10 \times 10^{-4}$ & $15(43)$ & $1(3)$ & $4(11)$ & $12(34)$ & $1(3)$ & $1(3)$ & $1(3)$ \\
\hline \multirow{4}{*}{ Rifampycin } & $12.5 \times 10^{-4}$ & $17(49)$ & $5(14)$ & $9(26)$ & $1(3)$ & $1(3)$ & $1(3)$ & $1(3)$ \\
\hline & $25 \times 10^{-4}$ & $14(40)$ & $2(6)$ & $13(37)$ & $3(9)$ & $1(3)$ & $1(3)$ & $1(3)$ \\
\hline & $50 \times 10^{-4}$ & $12(34)$ & $1(3)$ & $7(20)$ & $9(26)$ & $3(9)$ & $2(6)$ & $1(3)$ \\
\hline & $100 \times 10^{-4}$ & $11(31)$ & $4(11)$ & $6(17)$ & $10(29)$ & $2(6)$ & $1(3)$ & $1(3)$ \\
\hline \multirow{4}{*}{ Tetracycline } & $6.25 \times 10^{-4}$ & $24(69)$ & $4(11)$ & $2(6)$ & $2(6)$ & $1(3)$ & $1(3)$ & $1(3)$ \\
\hline & $12.5 \times 10^{-4}$ & $21(60)$ & $2(6)$ & $5(14)$ & $2(6)$ & $3(9)$ & $1(3)$ & $1(3)$ \\
\hline & $25 \times 10^{-4}$ & $17(49)$ & $4(11)$ & $8(23)$ & $2(6)$ & $2(6)$ & $1(3)$ & $1(3)$ \\
\hline & $50 \times 10^{-4}$ & $16(46)$ & $3(9)$ & $7(20)$ & $5(14)$ & $2(6)$ & $1(3)$ & $1(3)$ \\
\hline \multirow{4}{*}{ Vankomycin } & $6.25 \times 10^{-2}$ & $17(49)$ & $5(14)$ & $9(26)$ & $1(3)$ & $1(3)$ & $1(3)$ & $1(3)$ \\
\hline & $12.5 \times 10^{-2}$ & $15(43)$ & $2(6)$ & $13(37)$ & $2(6)$ & $1(3)$ & $1(3)$ & $1(3)$ \\
\hline & $25 \times 10^{-2}$ & $12(34)$ & $4(11)$ & $10(29)$ & $6(17)$ & $1(3)$ & $1(3)$ & $1(3)$ \\
\hline & $50 \times 10^{-2}$ & $11(31)$ & $8(23)$ & $3(9)$ & $7(20)$ & $4(11)$ & $1(3)$ & $1(3)$ \\
\hline \multirow{4}{*}{ Gentamicin } & $12.5 \times 10^{-2}$ & $25(71)$ & $4(11)$ & $1(3)$ & $2(6)$ & $1(3)$ & $1(3)$ & $1(3)$ \\
\hline & $25 \times 10^{-2}$ & $23(66)$ & $5(14)$ & $3(9)$ & $1(3)$ & $1(3)$ & $1(3)$ & $1(3)$ \\
\hline & $50 \times 10^{-2}$ & $20(57)$ & $6(17)$ & $4(11)$ & $1(3)$ & $2(6)$ & $1(3)$ & $1(3)$ \\
\hline & 1 & $16(46)$ & $3(9)$ & $11(31)$ & $1(3)$ & $2(6)$ & $1(3)$ & $1(3)$ \\
\hline
\end{tabular}

*Disk diameter *

\section{Conclusion}

This study demonstrated that there were large resistance differences between the 150 isolates of two species against the used antibiotics. The origin of antibiotic resistances in the bacteria is unknown, but it is an established fact that LAB can gain antibiotic resistances from other microorganism and mutation. It is a great public concern that commensal bacterial populations from food could act as a reservoir for antibiotic resistance genes. Resistance genes could ultimately be transferred to human pathogens and thereby cause a failure in the treatment of infections. Consequently, foods colonized by the bacteria that harbor such transferable antibiotic resistance genes are becoming a major concern. We suggest that these antibiotic resistance features of the microorganisms must be taken into account when considered as potential starters.

\section{References}

Ammor M, Florez AB, Mayo B. 2007. Antibiotic resistance in non-enterococcal lactic acid bacteria and bifidobacteria. Food Microbiol 24: 559-570.

Aslim B, Bayatli Y, Yuksekdag ZN. 2004. Antibiotic resistance and plasmid DNA contents of Streptococcus thermophilus strains isolated from Turkish yoghurts. J Food Sci Tech Mys 41: 18-22.

Bronzwaer SLAM, Cars O, Buchholz U, Molstad S, Goettsch W, Veldhuijzen IK, Kool JL, Sprenger MJW, Degener JE, Resistance EA. 2002. A European study on the relationship between antimicrobial use and antimicrobial resistance. Emerg Infect Dis 8: 278-282.

Carr FJ, Chill D, Maida N, 2002. The lactic acid bacteria: A literature survey. Crit Rev Microbiol 28: 281-370.

Florez AB, Delgado S, Mayo B. 2005. Antimicrobial susceptibility of lactic acid bacteria isolated from a cheese environment. Can J Microbiol 51: 51-58. 
Fraqueza MJ. 2015. Antibiotic resistance of lactic acid bacteria isolated from dry-fermented sausages. Int J Food Microbiol 212: 76-88.

Gezginc Y, Topcal F, Comertpay S, Akyol I. 2015. Quantitative analysis of the lactic acid and acetaldehyde produced by Streptococcus thermophilus and Lactobacillus bulgaricus strains isolated from traditional Turkish yogurts using HPLC. J Dairy Sci 98: 1426-1434.

Levy SB, Marshall B. 2004. Antibacterial resistance worldwide: causes, challenges and responses. Nat Med 10: S122-S129.

Mazel D, Davies J. 1999. Antibiotic resistance in microbes. Cell Mol Life Sci 56: 742-754.

Normark BH, Normark S. 2002. Evolution and spread of antibiotic resistance. J Intern Med 252: 91-106.

Petrova PM, Gouliamova DE. 2006. Rapid screening of plasmid-encoded small hsp-genes in Streptococcus thermophilus. Curr Microbiol 53: 422-427.

Salyers AA, Gupta A, Wang YP. 2004. Human intestinal bacteria as reservoirs for antibiotic resistance genes. Trends Microbiol 12: 412-416.
Shazali N, Foo HL, Loh TC, Choe DW, Rahim RA. 2014. Prevalence of antibiotic resistance in lactic acid bacteria isolated from the faeces of broiler chicken in Malaysia. Gut Pathog 6.

Teuber M, Meile L, Schwarz F. 1999. Acquired antibiotic resistance in lactic acid bacteria from food. Anton Leeuw Int J G 76: 115-137.

Thompson JD, Gibson TJ, Plewniak F, Jeanmougin F, Higgins DG. 1997. The CLUSTAL_X windows interface: flexible strategies for multiple sequence alignment aided by quality analysis tools. Nucleic Acids Res 25: 4876-4882.

Wang HH, Manuzon M, Lehman M, Wan K, Luo HL, Wittum TE, Yousef A, Bakaletz LO. 2006. Food commensal microbes as a potentially important avenue in transmitting antibiotic resistance genes. Fems Microbiology Letters 254: 226-231.

Winsley T, van Dorst JM, Brown MV, Ferrari BC. 2012. Capturing Greater 16S rRNA Gene Sequence Diversity within the Domain Bacteria. Appl Environ Microb 78: 59385941. 